\title{
TJBF RATIONAL EXPECTATIONS, IRRATIONAL EXUBERANCE: LINKAGE BETWEEN U.S. INVESTORS AND PACIFIC-BASIN STOCK RETURNS
}

\author{
Rahul Verma \\ The University of Houston, United States of \\ America
}

\begin{abstract}
We shed new light on the relevance of rational expectations and irrational exuberance of U.S. individual and institutional investors on Pacific-Basin stock returns. We find insignificant effects of irrational exuberance and significant effect of rational expectations on Asian markets with varying degrees of intensity. There are greater responses of Hong Kong, Malaysia, Philippines, and Singapore while weaker linkages with Taiwan, Thailand, and Korea. Overall evidence suggests that rational expectations of institutional investors are transmitted to a greater extent than those of individual investors. These results are consistent with the view that international effects of the U.S. market can be attributed to rational investor sentiments.
\end{abstract}

Key words: Stock returns, Investor sentiment, VAR model, Asia Pacific markets

JEL Classification: G12, G14, C22

\section{Introduction}

The central task in financial economics is to identify the systematic risks that drive asset prices and expected returns (Campbell, 2000; Cochrane, 2000). However, in recent years there has been a growing debate on the possible linkages between the behavioral aspects of investors and stock prices. Financial economics has become more receptive to imperfect rational explanations, and investor psychology has emerged as a major determinant of asset prices. After decades of study, the sources of risk premium in purely rational models are well understood; while, dynamic psychology based asset pricing theories are still in 
the infancy stage. This debate surrounding asset pricing has identified two prime suspects in setting stock prices: fundamentals and investor sentiments.

The theoretical framework describing the role of investor sentiments in determining stock prices is provided by researchers such as Black (1986), Trueman (1988), DeLong, Shleifer, Summers and Waldman [DSSW henceforth] (1991, 1990), Shleifer and Summers (1990), Lakonishok, Shleifer and Vishny (1991), Campbell and Kyle (1993), Shefrin and Statman (1994), Palomino (1996), Barberis, Shleifer and Vishny (1998), Daniel, Hirshleifer and Subramanyam (1998) and Hong and Stein (1999). A direct implication of these studies is certain groups of investors (noise traders), who often do not make investment decisions based on a company's fundamentals, are capable of affecting stock prices by way of unpredictable changes in their sentiments.

Following the 'noise trader model' of DSSW (1990), several empirical studies examine the influence of investor sentiments on stock prices (Brown and Cliff, 2004a, 2004b; Lee et al. 2002; Fisher and Statman, 2000; Clarke and Statman, 1998; Solt and Statman 1988; De Bondt, 1993). Overall, these studies provide evidence in favor of strong co-movements between investor sentiment and the stock market returns recognizing the existence of individual investor sentiments, as well as institutional investor sentiments.

The previous research mainly focuses on the effect of investor sentiments on the U.S. market while less attention has been given to its relevance in the international context. For example, little has been done to understand the degree of the relationship between the U.S. individual and institutional investor sentiments and Pacific-Basin stock returns. Given strong empirical evidence on the strengthening response of Pacific-Basin stock markets to the U.S. market over time (Soydemir, 2005; Kim, 2003; Ratanapakorn and Sharma, 2002; Janakiramanan and Lamba, 1998; Park and Fatemi, 1993) it is important to analyze whether the expectations of the U.S. investors is an important player in propagating U.S. stock market movements abroad. We shed new light on the relevance of the rational expectations and irrational exuberance of the U.S. investors in determining stock returns of Hong Kong, Malaysia, Philippines, Singapore, Taiwan, Thailand, and Korea.

Using the investor sentiments data at the individual and institutional level, provided by American Association of Individual Investors and Investors Intelligence and the vector auto regression (VAR) models we find the following results: first, we do not find any significant effect of irrational exuberance of the U.S. investors on Pacific-Basin stock market returns. Second, we find significant relationship of varying degrees of strength between the rational expectations of the U.S. individual and institutional investors and Asian stock returns except in the cases of Taiwan and Thailand. Third, there are greater effects of rational expectations of the institutional investors than individual investors on theses stock returns. These findings suggest that the international effects of the U.S. stock market can be attributed to fundamental trading and not to noise trading in the U.S. market. These results are consistent with the view that investor sentiment in the U.S. is an important player in propagating U.S. stock market 
movements abroad. Therefore it is important for policymakers to consider such spillover effects in their international policy making decisions and for investors in their portfolio allocation decisions involving stock markets movements.

This remainder of this paper is organized as follows: section two reviews the existing literature on investor sentiments and stock prices while section three presents the model. Section four presents the data. Section five reviews the econometric methodology. Section six presents empirical findings. Section seven concludes.

\section{Previous work on investor sentiments and stock prices}

The concept of investor sentiments, noise trading and its role in the financial markets is first given by Black (1986). Black (1986) labels non rational investors as "noise traders", who have no access to inside information, and act irrationally in response to news that conveys little information about fundamentals. However, there are two opposing views in the literature on the relevance of noise traders in determining stock prices. Based on Friedman (1953) and Fama (1965), it is argued that noise traders are irrelevant and cannot survive since they are driven out of the market by rational arbitrageurs. For example, West (1988) states "there is little direct evidence that trading by naïve investors plays a substantial role in stock price determination". On the contrary, Black (1986) and Trueman (1988) argue that noise traders induce necessary liquidity in the market, and therefore provide incentives for informed investors to trade.

The notable work of DSSW (1990, and 1991) models the influence of noise trading on equilibrium prices. They argue that noise traders falsely believe that they have special information about the future prices and the unpredictability of their sentiments brings an additional risk in the market. They may get pseudo signals from analysts, brokers, consultants and irrationally believe that these signals carry information. Their 'noise trader' model shows that a nonfundamental factor exists in the form of investor sentiments that is priced in equilibrium. Furthermore, noise traders as a group can earn expected returns higher than rational investors and can also survive in terms of wealth gain in the long run, due to unpredictability in their sentiments.

Campbell and Kyle (1993) model the competitive interaction between noise and informed traders and its consequent effect on stock prices. Shleifer and Summers (1990) present an alternative to the efficient markets paradigm that stresses the role of investor sentiments and limited arbitrage in determining stock prices. They show that the assumption of limited arbitrage is more plausible as a description of risky asset markets than the assumption of complete arbitrage on which market efficiency hypothesis is based. This implies that changes in investor sentiments are not fully countered by arbitrageurs therefore may affect stock returns. Similarly, Shefrin and Statman (1994) show the interaction between noise and informed traders and present the behavioral capital asset pricing theory. They argue that in contrast to information, sentiments of noise traders' act as a second driver which takes the market away from efficiency. 
Lakonishok, Shleifer and Vishny (1991) find that in small markets institutional investors influence prices. Along the same lines, Palomino (1996) extends the DSSW (1990) model for an imperfectly competitive market and shows that noise traders may earn higher return and obtain higher expected utility than rational investors. Wang (2001) examines the dynamics of non-rational investors find that bullish sentiments can survive while bearish sentiment cannot survive in the long run.

Overall, these models suggest that the unpredictability in investor sentiments of noise traders acting as a group can introduce a systematic risk that is priced in markets. Following these predictions, several empirical studies have examined the role of investor sentiments on stock pricing. These studies have either used indirect measures or direct measures of investor sentiments.

Studies using indirect measures include the following proxies: close-ended fund's discount (Gemmill and Thomas, 2002; Baker \& Wurgler, 2005; Sias, Starks and Tinic, 2001; Neal and Whitney, 1998; Swaminathan, 1996; Elton, Gruber and Busse, 1998; Chan, Kan and Miller, 1993; Lee, Shleifer and Thaler, 1991); market performance based measures (Brown and Cliff, 2004a); trading activity based measures (Brown and Cliff, 2004a; Neal and Whitney, 1998); derivative variables (Brown and Cliff, 2004a); dividend premium (Baker and Wurgler, 2005); and IPOs related measures (Baker \& Wurgler, 2005; Brown and Cliff, 2004a). Overall these studies do not provide a consensus on whether the proxies chosen are appropriate measures of investor sentiment and also show mixed results in their debate on the linkages between sentiments and stock returns.

Studies using direct measures employ sentiment surveys data that indicate the expectations of market participants. Research related to individual investors sentiments find strong co-movements with stock market returns (Brown and Cliff, 2004a; De Bondt, 1993) and mixed results regarding its role in short term predictability of stock prices (Brown and Cliff, 2004a; Fisher and Statman, 2000). Similarly, studies examining institutional sentiments find strong co-movements with stock market returns (Brown and Cliff, 2004a) and mixed results regarding its short run implications on stock prices (Brown and Cliff, 2004a; Lee, Jiang and Indro, 2002; Clarke and Statman, 1998; Solt and Statman, 1988). Also, Brown and Cliff (2004b) examine the long run implications of institutional investor sentiments and find strong relationships with long horizon stock returns. Overall, these studies provide powerful and consistent empirical support for the hypothesis that stock prices are affected by individual and institutional investor sentiments.

\section{Model}

Previous studies suggest that some shifts in investor sentiments are fully rational i.e., expectations based on the risk factors, while some are irrational exuberance, induced by the noise (Baker and Wurgler, 2005; Brown and Cliff, 
2004b, Shleifer and Summers, 1990). Hirshleifer (2001) also relates expected returns to both risks and investor mis-valuation. When an investor is bullish or bearish, then this could be a rational reflection of future period's expectation or irrational enthusiasm or a combination of both. Therefore it is quite possible that international stock returns are affected by both rational (risk based) and irrational (noise) components of the U.S. investor sentiments. We follow the approach of Baker and Wurgler (2005) to capture the irrational component of investor sentiments by regressing sentiment indicators to a set of risk factors and computing the residuals. Accordingly, we formulate equations (1) and (2):

$$
\begin{aligned}
& \text { Sentt }_{1 t}=\gamma_{0}+\gamma_{j} \sum_{j=1}^{J} \text { Fund }_{j t}+\xi_{t} \\
& \text { Sentt }_{2 t}=\theta_{0}+\theta_{j} \sum_{j=1}^{J} \text { Fund }_{j t}+\vartheta_{t}
\end{aligned}
$$

where $\gamma_{0}$ and $\theta_{0}$ are constants, $\gamma_{j}$ and $\theta_{j}$ are the parameters to be estimated; $\zeta_{t}$ and $g_{t}$ are the random error terms. Sentt ${ }_{1 t}$ and Sentt $2 t$ represent the shifts in sentiments of individual and institutional investors respectively at time $t$. Fund $d_{j t}$ is the set of fundamentals representing rational expectations based on risk factors that have been shown to carry non-redundant information in conditional asset pricing literature. The fitted values of equations (1) and (2) capture the rational component of sentiments (i.e. Sent $\hat{t}_{1 t}$ and $\operatorname{Sent} \hat{t}_{2 t}$ ). On the other hand the residual of equations (1) and (2) capture the irrational component of sentiments (i.e. $\zeta_{t}$ and $\theta_{t}$ ).

Next, we analyze the extent to which Pacific-Basin stock returns are affected by rational expectations and irrational exuberance of the U.S. individual and institutional investors. Accordingly, the sentiment variables are decomposed into the rational and irrational components based on equations (1) and (2) and included in the return generating process as:

$$
R_{i t}=\alpha_{0}+\alpha_{1} \operatorname{Sent} \hat{t}_{1 t}+\alpha_{2} \operatorname{Sent} \hat{t}_{2 t}+\alpha_{3} \xi_{t}+\alpha_{4} \square_{t}+\rho_{t}
$$

where $\alpha_{0}$ is a constant while $\alpha_{1}, \alpha_{2}, \alpha_{3}$ and $\alpha_{4}$ are the parameters to be estimated; $\rho_{t}$ is the random error term. $R_{i t}$ is the returns for the $i^{\text {th }}$ PacificBasin stock market at time $t$. Specifically, the parameters $\alpha_{1}$ and $\alpha_{2}$ capture the effects of rational expectations on part of individual and institutional investors respectively; while $\alpha_{3}$ and $\alpha_{4}$ capture the effects of irrational exuberance of individual and institutional investors respectively. We also place importance on jointly modeling the sentiments of individual and institutional investors to avoid misspecification. Specifically, shocks originating from sentiments of one class of investors not considered might mistakenly be seen as a disturbance originating from sentiments of another class of investors in the analysis. 


\section{Data}

We obtain all data in monthly intervals from October 1988 to April 2004. To measure sentiments of market participants, we employ survey data similar to the ones used in the literature. The institutional investors participate in the market for living while the individual investors' primary line of business is outside the stock market (Brown and Cliff, 2004a). Our choice of individual investor sentiment index is based on Brown and Cliff (2004a), Fisher and Statman (2000) and DeBondt (1993) which use the survey data of American Association of Individual Investor (AAII). Beginning July 1987, AAII conducts a weekly survey asking for the likely direction of the stock market during the next six months (up, down or the same). The participants are randomly chosen from approximately 100,000 AAII members. Each week, AAII compiles the results based on survey answers and labels them as bullish, bearish or neutral. These results are published as 'investor sentiment' in monthly editions of AAII Journal. The sentiment index for individual investors is computed as the spread between the percentage of bullish investors and percentage of bearish investors (BullBear). Since this survey is targeted towards individual investors, it is primarily a measure of individual investor sentiments.

Our choice of institutional investor sentiment index is based on Brown and Cliff (2004a, 2004b), Lee et al. (2002), Clarke and Statman (1998) and Solt and Statman (1988) which use the survey data of Investors Intelligence (II), an investment service based in Larchmont, New York. II compiles and publishes data based on a survey of investment advisory newsletters. To overcome the potential bias problem towards buy recommendation, letters from brokerage houses are excluded. Based on the future market movements the letters are labeled as bullish, bearish or correction (hold). The sentiment index for the institutional investor is found by calculating the spread between the percentage of bullish investors and percentage of bearish investors. Because authors of these newsletters are market professionals, the II series is interpreted as a proxy for institutional investor sentiments. We analyze the response of seven Pacific-Basin stock markets, Korea, Malaysia, Philippines, Singapore, Taiwan, Thailand and Korea. The market variable identified for these countries are the major indexes in their respective stock markets. The continuously compounded returns are computed from the local currency denominated stock market indexes obtained from the Datastream.

We include the following variables as risk factors that have been shown to carry non-redundant information in the asset pricing literature: (i) Economic growth (Fama, 1970; Schwert, 1990) measured as the monthly changes in the industrial production index (ii) Short term interest rates (Campbell, 1991) measured as the yield on one month U.S. Treasury Bill (iii)Economic risk premia (Ferson and Harvey, 1991; Campbell, 1987) measured as the term structure of interest rates (difference in monthly yields on three month and one month Treasury bills (iv) Future economic expectations variables (Fama, 1990) measured as the term spread (yields spread on the 10 year U.S. Treasury bond 
and three month Treasury bill) (v) Business conditions (Fama and French, 1989; Keim and Stambaugh, 1986) measured as the default spread (difference in yields on Baa and Aaa corporate bonds)(vi) Dividend yield (Hodrick, 1992; Fama and French, 1988; Campbell and Shiller, 1988a, 1988b) measured as the dividend yield for the value weighted Center for Research in Security Prices (CRSP) index over the past 12 months (vii) Inflation (Sharpe, 2002; Fama and Schwert, 1977) measured as the monthly changes in the consumer price index (viii) Excess returns on market portfolio(Lintner, 1965; Sharpe, 1964) measured as the value-weighted returns on all NYSE, AMEX, and NASDAQ stocks minus the one-month Treasury bill rate (ix) Premium on portfolio of small stocks relative to large stocks (SMB) (Fama and French, 1993). SMB (Small minus Big) is the average return on three small portfolios minus the average return on three big portfolios (x) Premium on portfolio of high book/market stocks relative to low book/market stocks (HML) (Fama and French, 1993). This Fama/French benchmark factor is constructed from six size/book-to-market benchmark portfolios that do not include hold ranges and do not incur transaction costs. HML (High minus Low) is the average return on two value portfolios minus the average return on two growth portfolios. (xi) Momentum factor (UMD) (Jegadeesh and Titman, 1993). UMD (Up minus Down) is the average return on the two high prior return portfolios minus the average return on the two low prior return portfolios (xii) Currency fluctuation (Elton and Gruber, 1991) measured as the changes in 15-country trade weighted basket of currencies.

The data on economic growth, business conditions and inflation are obtained from Datastream; short term interest rates, economic risk premium, future economic variables and currency fluctuations are obtained from Federal Reserve Bank of St. Louis; dividend yield and excess return on market portfolio from CRSP; and SMB, HML and UMD from Kenneth French Data Library at Tuck School of Business, Dartmouth College.

Table 1 reports the descriptive statistics of the above mentioned variables. The mean of $S_{n t t}$ and $S n t t_{2}$ are approximately $11 \%$ and $9 \%$ respectively. This suggests both individual and institutional investors have been bullish during most of the sample period. Interestingly, individual investors have been more bullish than institutional investors. The standard deviations of Pacific-Basin stock markets are very high indicating their extremely volatile nature during the sample period. Among these markets Hong Kong seems to have provided the highest return to investors, while the mean returns in case of Thailand and Korea are negative. Most of the variables relating to the risk factors have shown less variability as compared to the investor sentiments and Asian stock returns.

\section{Table 1: Descriptive Statistics}

The variables are individual investor sentiments $\left(\right.$ Sentt $\left._{1}\right)$, institutional investor sentiments (Sentt ${ }_{2}$ ), economic growth(IIP), short term interest rates (T30), economic risk premiums (T90-T30), future economic variables (B10-T30), business conditions (Baa-Aaa), dividend yield (Div.), inflation (INF), excess returns on market portfolio $\left(\mathrm{R}_{\mathrm{m}}\right)$, premium 
on portfolio of small stocks relative to large stocks (SMB), premium on portfolio of high book/market stocks relative to low book/market stocks (HML), momentum factors (UMD), currency fluctuations (USD), and stock market returns on Hong Kong (Hong Kong), Malaysia (Malaysia), Philippines (Philippines), Singapore (Singapore), Taiwan (Taiwan), Thailand (Thailand), and Korea (Korea).

\begin{tabular}{lccccccc}
\hline & Mean & Median & Maximum & Minimum & Std. Dev. & Skewness & Kurtosis \\
\hline Sentt $_{1}$ & 0.1143 & 0.1200 & 0.5100 & -0.3500 & 0.1760 & -0.0863 & 2.6626 \\
Sentt $_{2}$ & 0.0896 & 0.1100 & 0.3640 & -0.3420 & 0.1413 & -0.5373 & 2.9513 \\
IIP & 0.0096 & 0.0147 & 0.1011 & -0.1094 & 0.0389 & -0.5279 & 3.5607 \\
T30 & 0.0026 & 0.0032 & 0.0199 & -0.0121 & 0.0052 & -0.1152 & 3.2783 \\
T90-T30 & 0.0043 & 0.0041 & 0.0080 & 0.0021 & 0.0013 & 0.4793 & 2.9139 \\
B10_T30 & 0.0004 & 0.0004 & 0.0017 & -0.0003 & 0.0004 & 0.8185 & 3.7719 \\
Baa-Aaa & 0.0071 & 0.0078 & 0.0549 & -0.0440 & 0.0181 & -0.0562 & 3.1558 \\
Div & 0.0078 & 0.0073 & 0.0144 & 0.0053 & 0.0018 & 1.1020 & 4.3580 \\
INF & 0.0127 & 0.0153 & 0.1141 & -0.1437 & 0.0408 & -0.4639 & 3.9027 \\
R & 0.0026 & 0.0023 & 0.0103 & -0.0012 & 0.0021 & 0.9335 & 4.3616 \\
SMB & 0.0031 & 0.0077 & 0.0994 & -0.1655 & 0.0414 & -0.7543 & 4.3240 \\
HML & -0.0012 & -0.0028 & 0.2138 & -0.1626 & 0.0382 & 1.0244 & 11.0803 \\
UMD & 0.0024 & 0.0009 & 0.1367 & -0.1205 & 0.0363 & 0.4417 & 5.3273 \\
USD & 1.1658 & 1.3200 & 18.2100 & -25.1300 & 4.5224 & -0.7366 & 11.7315 \\
Hong Kong & 0.0120 & 0.0139 & 0.2645 & -0.3482 & 0.0872 & -0.2028 & 5.0505 \\
Malaysia & 0.0005 & 0.0006 & 0.2895 & -0.2784 & 0.0991 & 0.0815 & 4.2293 \\
Philippines & 0.0060 & -0.0016 & 0.3317 & -0.2989 & 0.0974 & 0.2858 & 4.6905 \\
Singapore & 0.0048 & 0.0057 & 0.2484 & -0.2107 & 0.0757 & 0.0797 & 4.3745 \\
Taiwan & 0.0014 & 0.0007 & 0.3324 & -0.1746 & 0.0910 & 0.7308 & 4.0350 \\
Thailand & -0.0057 & -0.0092 & 0.2843 & -0.2817 & 0.1087 & 0.2910 & 3.5018 \\
Korea & -0.0015 & -0.0097 & 0.3945 & -0.3181 & 0.0998 & 0.5246 & 4.7757 \\
\hline & & & & & & &
\end{tabular}

\section{Econometric methodology}

We choose the VAR modeling technique (Sims, 1980) as an appropriate econometric methodology to investigate the postulated relationships. The rationale for doing so lies in the arguments of Brown and Cliff (2004a \& 2004b) and Lee et al. (2002) which suggest that stock market returns and investor sentiments may act as a system. Our approach is also consistent with studies such as Soydemir (2005), Kim (2003), Ratanapakorn and Sharma (2002), Janakiramanan and Lamba (1998), and Park and Fatemi (1993) which have employed the VAR models to analyze the linkages between the U.S. and PacificBasin stock markets. 
The VAR specification allows the researchers to do policy simulations and integrate Monte Carlo methods to obtain confidence bands around the point estimates (Doan, 1988; Genberg et al. 1987; Hamilton, 1994). The likely response of one variable at time $t, t+1, t+2$ etc. to a one time unitary shock in another variable at time $t$ can be captured by impulse response functions. As such they represent the behavior of the series in response to pure shocks while keeping the effect of other variables constant. Since, impulse responses are highly non-linear functions of the estimated parameters, confidence bands are constructed around the mean response. Responses are considered statistically significant at the 95\% confidence level when the upper and lower bands carry the same sign. Thus VAR model captures the dynamic feedback effects in a relatively unconstrained fashion and is therefore a good approximation to the true data generating process. We express the VAR model as:

$$
Z(t)=C+\bullet_{s=1}^{m} A(s) Z(t-m)+\varepsilon(t)
$$

where, $Z(t)$ is a column vector of variables under consideration, $C$ is the deterministic component comprised of a constant, $A(s)$ is a matrix of coefficients, $m$ is the lag length and $\varepsilon(t)$ is a vector of random error terms.

\section{Table 2: Cross-correlations of variables relating to fundamentals}

The variables are economic growth (IIP), short term interest rates (T30), economic risk premiums (T90), future economic variables (B10), business conditions (Baa), dividend yield (Div), inflation (INF), excess returns on market portfolio $\left(\mathrm{R}_{\mathrm{m}}\right)$, premium on portfolio of small stocks relative to large stocks (SMB), premium on portfolio of high book/market stocks relative to low book/market stocks (HML), momentum factors (UMD), and currency fluctuations (USD).

\begin{tabular}{|c|c|c|c|c|c|c|c|c|c|c|c|}
\hline & B10 & Baa & IIP & HML & INF & $\mathrm{R}_{\mathrm{m}}$ & DIV & SMB & $\mathrm{T} 30$ & T90 & UMD USD \\
\hline B10 & 1.00 & & & & & & & & & & \\
\hline Baa & 0.00 & 1.00 & & & & & & & & & \\
\hline IIP & -0.15 & -0.39 & 1.00 & & & & & & & & \\
\hline HML & 0.06 & -0.06 & 0.05 & 1.00 & & & & & & & \\
\hline INF & -0.02 & 0.16 & -0.15 & 0.00 & 1.00 & & & & & & \\
\hline $\mathrm{R}_{\mathrm{m}}$ & 0.26 & -0.01 & -0.10 & -0.56 & -0.17 & 1.00 & & & & & \\
\hline DIV & 0.32 & 0.02 & -0.11 & -0.47 & -0.16 & 0.97 & 1.00 & & & & \\
\hline SMB & -0.20 & -0.04 & -0.05 & -0.50 & 0.00 & 0.17 & -0.04 & 1.00 & & & \\
\hline $\mathrm{T} 30$ & 0.14 & 0.40 & -0.28 & -0.06 & 0.26 & -0.07 & 0.02 & -0.13 & 1.00 & & \\
\hline T90 & 0.32 & 0.25 & -0.19 & -0.15 & 0.09 & 0.14 & 0.15 & -0.01 & 0.19 & 1.00 & \\
\hline UMD & 0.20 & -0.06 & 0.00 & -0.20 & -0.10 & 0.03 & -0.03 & 0.20 & 0.01 & -0.14 & 1.00 \\
\hline USD & -0.03 & -0.09 & 0.17 & 0.19 & -0.14 & -0.16 & -0.15 & 0.00 & 0.00 & -0.04 & $0.00 \quad 1.00$ \\
\hline
\end{tabular}


Table 3: Effects of fundamentals on individual and institutional investor sentiments

The variables are individual investor sentiments (Sentt $)_{1}$, institutional investor sentiments (Sentt ${ }_{2}$ ), economic growth (IIP), short term interest rates (T30), economic risk premiums (T90), future economic variables (B10), business conditions (Baa), dividend yield (Div), inflation (INF), excess returns on market portfolio $\left(\mathrm{R}_{\mathrm{m}}\right)$, premium on portfolio of small stocks relative to large stocks (SMB), premium on portfolio of high book/market stocks relative to low book/market stocks (HML), momentum factors (UMD), and currency fluctuations (USD).

$$
\operatorname{Sentt}_{i t}=\lambda_{i 0}+\lambda_{i j} \bullet_{j=1}^{J} \text { Fund }_{j i t}+\xi_{i t}
$$

\begin{tabular}{|c|c|c|}
\hline Variables & Sentt $_{1}$ & Sentt $_{2}$ \\
\hline B10 & $\begin{array}{l}-0.96 \\
(0.88)\end{array}$ & $\begin{array}{c}0.49 \\
(0.71)\end{array}$ \\
\hline Baa & $\begin{array}{c}-29.93 * * * \\
(8.35)\end{array}$ & $\begin{array}{l}-4.82 \\
(8.27)\end{array}$ \\
\hline IIP & $\begin{array}{c}1.30 \\
(2.77)\end{array}$ & $\begin{array}{l}-2.22 \\
(2.20)\end{array}$ \\
\hline HML & $\begin{array}{c}1.44 * * * \\
(0.53)\end{array}$ & $\begin{array}{c}1.14 * * * \\
(0.46)\end{array}$ \\
\hline INF & $\begin{array}{c}-18.28 * * * \\
(6.60)\end{array}$ & $\begin{array}{l}-8.35 \\
(6.06)\end{array}$ \\
\hline $\mathrm{R}_{\mathrm{m}}$ & $\begin{array}{c}-6.75^{* *} \\
(3.29)\end{array}$ & $\begin{array}{l}-3.60 \\
(2.66)\end{array}$ \\
\hline DIV & $\begin{array}{c}8.32 * * * \\
(3.31)\end{array}$ & $\begin{array}{l}4.50^{*} \\
(2.71)\end{array}$ \\
\hline SMB & $\begin{array}{c}2.78 * * * \\
(0.80)\end{array}$ & $\begin{array}{c}1.99 * * * \\
(0.66)\end{array}$ \\
\hline T30 & $\begin{array}{c}7.47 \\
(13.57)\end{array}$ & $\begin{array}{c}-6.83 \\
(11.51)\end{array}$ \\
\hline T90 & $\begin{array}{c}-13.11 \\
36.71\end{array}$ & $\begin{array}{l}-31.70 \\
(31.64)\end{array}$ \\
\hline UMD & $\begin{array}{c}0.00 \\
(0.00)\end{array}$ & $\begin{array}{c}0.00 \\
(0.00)\end{array}$ \\
\hline USD & $\begin{array}{c}0.00 \\
(0.01)\end{array}$ & $\begin{array}{c}0.00 \\
(0.01)\end{array}$ \\
\hline $\mathrm{C}$ & $\begin{array}{c}0.29 * * * \\
(0.07)\end{array}$ & $\begin{array}{c}0.15^{* *} \\
(0.07)\end{array}$ \\
\hline R-squared & 0.304 & 0.161 \\
\hline SSR & 3.190 & 2.48 \\
\hline Akaike info criterion & -0.839 & -1.090 \\
\hline Schwarz criterion & -0.578 & -0.829 \\
\hline F-statistic & 4.989 & 2.186 \\
\hline Prob(F-statistic) & 0.000 & 0.015 \\
\hline
\end{tabular}


We first decompose the sentiments variables into rational and irrational components. In particular, we estimate two separate ordinary least square (OLS) regressions based on equations (1) and (2). To check the presence of multicollinearity, we estimate the cross-correlations between the variables related to fundamentals. The results of the cross correlations are reported in Table 2. The low correlations among most of the variables suggest that multicollinearity is not a major issue.

Table 3 reports the regression results based on equations (2) and (3). Individual investor sentiments are significantly related to business conditions, inflation, dividend yield, excess returns on market, SMB, and HML. Similarly, the sentiments of institutional investor sentiments are significantly related to dividend yield, SMB and

HML. These results are consistent with the arguments of Baker and Wurgler (2005), Brown and Cliff (2004b) and Shleifer and Summers (1990) that investor sentiments may contain a combination of both rational and irrational components and not necessarily only noise.

\section{Estimation results}

Before proceeding with the main results, we first check the time series properties of each variable by performing unit root tests. Table 4 reports the results of unit root tests using Augmented Dickey Fuller (ADF) test (Dickey and Fuller, 1979, 1981) and Kwiatkowski, Phillips, Schmidt, and Shin (1992) (KPSS test). Based

Table 4: Unit root test results

The variables are rational sentiments of individual investors (Rational $)_{1}$ ), rational sentiments of institutional investors $\left(\right.$ Rational $_{2}$ ), irrational sentiments of individual investors (Irrational $\left.{ }_{1}\right)$, irrational sentiments of institutional investors (Irrational ${ }_{2}$ ), and stock market returns on Hong Kong (Hong Kong), Malaysia (Malaysia), Philippines (Philippines), Singapore (Singapore), Taiwan (Taiwan), Thailand (Thailand), and Korea (Korea).

\begin{tabular}{|c|c|c|c|}
\hline & & ADF test & KPSS test \\
\hline Rational & & -4.019 & 0.112 \\
\hline Rational $^{1}$ & & -5.714 & 0.107 \\
\hline Irrational & & -6.337 & 0.098 \\
\hline Institutional_IR & & -3.989 & 0.153 \\
\hline Hong Kong & & -6.994 & 0.188 \\
\hline Malaysia & & -6.129 & 0.195 \\
\hline Philippines & & -6.764 & 0.092 \\
\hline Singapore & & -6.349 & 0.126 \\
\hline Taiwan & & -7.081 & 0.096 \\
\hline Thailand & & -6.537 & 0.114 \\
\hline Korea & & -6.421 & 0.134 \\
\hline \multicolumn{4}{|c|}{ Test critical values: } \\
\hline & $1 \%$ level & -3.469 & 0.739 \\
\hline & $5 \%$ level & -2.878 & 0.463 \\
\hline & $10 \%$ level & -2.575 & 0.347 \\
\hline
\end{tabular}


on the consistent and asymptotically efficient $A I C$ and SIC criteria (Diebold, 2003) and considering the loss in degrees of freedom, the appropriate number of lags is determined to be two. In the case of the ADF test, the null hypothesis of nonstationarity is rejected. In the KPSS test, the null hypothesis is that each series in stationary. We fail to reject the null hypothesis in the case of KPSS test. The inclusion of drift/trend terms in the ADF and KPSS test equations does not change these results (Dolado, Jenkinson, and Sosvilla-Rivero, 1990).

Given that the series are stationary in nature, we estimate a set of five variable VAR model for each of the seven Pacific-Basin stock countries. Each VAR model is composed of rational and irrational components of the U.S. individual and institutional investor sentiments and the stock returns of PacificBasin country being studied ${ }^{1}$.

\subsection{Variance Decomposition}

The decomposition of variance gives a quantitative measure to the causal relationship indicating how much the movement in one variable can be explained by other variables in terms of the percentage of the forecast error variance. Table 5 (Panels A through $\mathrm{G}$ ) shows the results of the innovation accounting procedure and reports the 1 through 10 day ahead forecast error variance of Pacific-Basin stock market returns accounted for by innovations in rational and irrational sentiments of the U.S. individual and institutional investors. In the case of Hong Kong (Panel A), total sentiments accounts for approximately $14 \%$ of the total forecast error variance. The major portion of such influences is due to rational sentiments of institutional investors which accounts for approximately 9\%. However, in the case of Malaysia (Panel B), total sentiments seem to have lesser influence on stock returns as compared to Honk Kong (approximately $11 \%$ ). Also, the rational sentiments of individual and institutional investors account for approximately $5 \%$ and $4 \%$ respectively, which are much greater than forecast error variances accounted by irrational sentiments. Panel C reports similar decomposition for Philippines stock market returns. The variance due to the total sentiments averages approximately between $12-13 \%$, of which rational sentiments of institutional investor has the highest contribution (approximately $8 \%$ ). Similar to the case of Korea, there is less influence of rational sentiments of individual investors. There is relatively very strong effect of rational sentiments of institutional investors in the case of Singapore (Panel D), as it accounts for $18-19 \%$ of the total forecast error variance. The effect of other components of sentiments is much less.

Panel E reports the forecast error variance in the case of Taiwan. The total sentiments accounts for approximately 8-9\%, which is the least among all the Pacific-Basin stock markets. Similar to the earlier findings, the rational sentiments

$1 \quad$ Our approach is similar to the one employed by Park and Fatemi (1993) which estimate a four variable VAR model for each of the seven Pacific-Basin countries instead of one model including all the variables to avoid irrelevant feedback relationships among stock markets. 
of institutional investors account for the maximum variance (approximately 4\%). Similar to Malaysia, rational individual investor sentiments accounts for greater proportion of the total variance (approximately 3.5\%). The results are very similar for Thailand (Panel F), where the rational institutional and individual investor sentiments account for approximately $4 \%$ and $3 \%$ respectively. Likewise, in the case of Korea (Panel G), rational sentiments of two classes of investors have approximately similar contribution.

Overall, the decomposition of forecast error variances of Pacific-Basin stock returns consistently suggests much higher effect of rational sentiments than the irrational sentiments. Specifically, in all the cases, rational sentiments of institutional investors is the most endogenous variable. These findings imply that the rational expectations of institutional investors are an important player in propagating the U.S. stock market movements in the Pacific-Basin region.

Table 5: Decomposition of forecast error variances of Asian stock returns

The variables are rational sentiments of individual investors (Rational), rational sentiments of institutional investors ( Rational $_{2}$ ), irrational sentiments of individual investors ( Irrational $_{1}$ ), irrational sentiments of institutional investors (Irrational ${ }_{2}$ ), and stock market returns on Hong Kong (Hong Kong), Malaysia (Malaysia), Philippines (Philippines), Singapore (Singapore), Taiwan (Taiwan), Thailand (Thailand), and Korea (Korea).

Panel A: Decomposition of Hong Kong

\begin{tabular}{ccccccc}
\hline \multicolumn{5}{c}{ By innovations in } \\
\hline Period & Rational $_{1}$ & Rational $_{2}$ & Irrational $_{1}$ & Irrational $_{2}$ & $\begin{array}{c}\text { Total } \\
\text { Sentiments }\end{array}$ & Hong Kong \\
\hline 1 & 1.9598 & 0.2250 & 1.0710 & 0.3259 & 3.2558 & 96.4183 \\
2 & 1.8287 & 5.9193 & 1.1767 & 1.8388 & 8.9248 & 89.2364 \\
3 & 1.9357 & 8.1152 & 1.3355 & 1.7897 & 11.3863 & 86.8240 \\
4 & 2.1002 & 8.8842 & 1.3669 & 1.7740 & 12.3513 & 85.8746 \\
5 & 2.0978 & 9.0597 & 1.3839 & 1.7761 & 12.5415 & 85.6824 \\
6 & 2.0981 & 9.0652 & 1.3898 & 1.8371 & 12.5530 & 85.6099 \\
7 & 2.0977 & 9.0693 & 1.3973 & 1.8539 & 12.5643 & 85.5817 \\
8 & 2.0982 & 9.0712 & 1.4070 & 1.8601 & 12.5765 & 85.5634 \\
9 & 2.0988 & 9.0735 & 1.4151 & 1.8619 & 12.5874 & 85.5507 \\
\hline 0 & 2.0995 & 9.0747 & 1.4212 & 1.8631 & 12.5954 & 85.5415 \\
\hline
\end{tabular}


Panel B: Decomposition of Malaysia

\begin{tabular}{ccccccc}
\hline \multicolumn{5}{c}{ By innovations in } \\
\hline Period & Rational $_{1}$ & Rational $_{2}$ & Irrational $_{1}$ & Irrational $_{2}$ & $\begin{array}{c}\text { Total } \\
\text { Sentiments }\end{array}$ & Malaysia $^{\text {Pron }}$ \\
\hline 1 & 0.1231 & 0.0159 & 0.0000 & 0.7613 & 0.9003 & 99.0997 \\
2 & 4.4359 & 3.4134 & 0.0581 & 1.3181 & 9.2256 & 90.7744 \\
3 & 4.1158 & 4.1651 & 0.2746 & 1.5794 & 10.1349 & 89.8651 \\
4 & 4.2303 & 4.5481 & 0.5493 & 1.5791 & 10.9067 & 89.0933 \\
5 & 4.1876 & 5.0159 & 0.5658 & 1.5929 & 11.3622 & 88.6378 \\
6 & 4.2917 & 5.0893 & 0.5663 & 1.5905 & 11.5377 & 88.4623 \\
7 & 4.3044 & 5.1322 & 0.5808 & 1.5904 & 11.6078 & 88.3922 \\
8 & 4.3318 & 5.1457 & 0.5806 & 1.5897 & 11.6477 & 88.3523 \\
9 & 4.3355 & 5.1576 & 0.5810 & 1.5893 & 11.6633 & 88.3367 \\
10 & 4.3402 & 5.1625 & 0.5811 & 1.5893 & 11.6730 & 88.3270 \\
\hline
\end{tabular}

Panel C: Decomposition of Philippines

\begin{tabular}{|c|c|c|c|c|c|c|}
\hline \multicolumn{7}{|c|}{ By innovations in } \\
\hline Period & Rational $_{1}$ & Rational $_{2}$ & Irrational $_{1}$ & Irrational $_{2}$ & $\begin{array}{c}\text { Total } \\
\text { Sentiments }\end{array}$ & Philippines \\
\hline 1 & 0.5410 & 1.1955 & 0.0040 & 1.0546 & 2.2541 & 97.2048 \\
\hline 2 & 1.0577 & 7.2477 & 0.6001 & 1.0808 & 8.9286 & 90.0136 \\
\hline 3 & 2.1692 & 7.5731 & 0.8720 & 1.3869 & 9.8320 & 87.9988 \\
\hline 4 & 2.2722 & 8.0619 & 0.9584 & 1.4514 & 10.4717 & 87.2561 \\
\hline 5 & 2.2930 & 8.4228 & 0.9587 & 1.4567 & 10.8382 & 86.8688 \\
\hline 6 & 2.3287 & 8.5021 & 0.9574 & 1.4576 & 10.9171 & 86.7542 \\
\hline 7 & 2.3483 & 8.5228 & 0.9583 & 1.4571 & 10.9382 & 86.7135 \\
\hline 8 & 2.3573 & 8.5282 & 0.9582 & 1.4568 & 10.9432 & 86.6994 \\
\hline 9 & 2.3608 & 8.5316 & 0.9581 & 1.4569 & 10.9467 & 86.6925 \\
\hline 10 & 2.3623 & 8.5335 & 0.9583 & 1.4571 & 10.9489 & 86.6888 \\
\hline
\end{tabular}

Panel D: Decomposition of Singapore

\begin{tabular}{|c|c|c|c|c|c|c|}
\hline \multicolumn{7}{|c|}{ By innovations in } \\
\hline Period & Rational $_{1}$ & Rational $_{2}$ & Irrational $_{1}$ & Irrational $_{2}$ & $\begin{array}{c}\text { Total } \\
\text { Sentiments }\end{array}$ & Singapore \\
\hline 1 & 0.1703 & 0.6844 & 0.1512 & 0.0686 & 1.0745 & 98.9255 \\
\hline 2 & 1.5614 & 14.6185 & 0.1918 & 1.3938 & 17.7656 & 82.2345 \\
\hline 3 & 2.5504 & 17.6776 & 0.1820 & 1.3821 & 21.7922 & 78.2078 \\
\hline 4 & 2.6344 & 18.6832 & 0.1793 & 1.3699 & 22.8668 & 77.1332 \\
\hline 5 & 2.6584 & 19.3584 & 0.2282 & 1.3560 & 23.6010 & 76.3990 \\
\hline
\end{tabular}




\begin{tabular}{ccccccc}
\hline 6 & 2.6557 & 19.3540 & 0.2468 & 1.4530 & 23.7095 & 76.2905 \\
7 & 2.6573 & 19.3594 & 0.2711 & 1.4755 & 23.7633 & 76.2367 \\
8 & 2.6605 & 19.3557 & 0.2876 & 1.4903 & 23.7941 & 76.2059 \\
9 & 2.6625 & 19.3613 & 0.3033 & 1.4928 & 23.8199 & 76.1801 \\
10 & 2.6669 & 19.3615 & 0.3142 & 1.4957 & 23.8383 & 76.1617 \\
\hline
\end{tabular}

Panel E: Decomposition of Taiwan

\begin{tabular}{ccccccc}
\hline \multicolumn{7}{c}{ By innovations in } \\
\hline Period & Rational $_{1}$ & Rational $_{2}$ & Irrational $_{1}$ & Irrational $_{2}$ & $\begin{array}{c}\text { Total Senti- } \\
\text { ments }\end{array}$ & Taiwan \\
\hline 1 & 1.7413 & 0.2104 & 0.1842 & 0.5202 & 2.6561 & 97.3439 \\
2 & 3.1608 & 4.1845 & 0.6226 & 0.6517 & 8.6196 & 91.3804 \\
3 & 3.5231 & 4.1651 & 0.6250 & 1.0546 & 9.3678 & 90.6322 \\
4 & 3.5875 & 4.1551 & 0.6269 & 1.0869 & 9.4564 & 90.5436 \\
5 & 3.5893 & 4.1535 & 0.6308 & 1.1201 & 9.4938 & 90.5062 \\
6 & 3.5877 & 4.1522 & 0.6413 & 1.1501 & 9.5313 & 90.4687 \\
7 & 3.5878 & 4.1512 & 0.6498 & 1.1654 & 9.5541 & 90.4459 \\
8 & 3.5876 & 4.1505 & 0.6560 & 1.1757 & 9.5699 & 90.4301 \\
9 & 3.5878 & 4.1502 & 0.6602 & 1.1821 & 9.5803 & 90.4197 \\
10 & 3.5881 & 4.1500 & 0.6631 & 1.1861 & 9.5873 & 90.4127 \\
\hline
\end{tabular}

Panel F: Decomposition of Thailand

\begin{tabular}{|c|c|c|c|c|c|c|}
\hline \multicolumn{7}{|c|}{ By innovations in } \\
\hline Period & Rational $_{1}$ & Rational $_{2}$ & Irrational $_{1}$ & Irrational $_{2}$ & $\begin{array}{c}\text { Total Senti- } \\
\text { ments }\end{array}$ & Thailand \\
\hline 1 & 0.8681 & 0.3833 & 1.5703 & 0.0913 & 0.8681 & 0.3833 \\
\hline 2 & 1.2603 & 2.3268 & 1.5154 & 1.2825 & 1.2603 & 2.3268 \\
\hline 3 & 3.0258 & 3.8247 & 1.6956 & 3.0017 & 3.0258 & 3.8247 \\
\hline 4 & 3.3520 & 4.3644 & 1.8083 & 2.9728 & 3.3520 & 4.3644 \\
\hline 5 & 3.4016 & 4.6906 & 1.8057 & 2.9724 & 3.4016 & 4.6906 \\
\hline 6 & 3.4531 & 4.7648 & 1.8053 & 2.9696 & 3.4531 & 4.7648 \\
\hline 7 & 3.4806 & 4.7984 & 1.8037 & 2.9707 & 3.4806 & 4.7984 \\
\hline 8 & 3.4954 & 4.8113 & 1.8032 & 2.9698 & 3.4954 & 4.8113 \\
\hline 9 & 3.5022 & 4.8190 & 1.8037 & 2.9692 & 3.5022 & 4.8190 \\
\hline 10 & 3.5058 & 4.8228 & 1.8044 & 2.9690 & 3.5058 & 4.8228 \\
\hline
\end{tabular}

Panel G: Decomposition of Korea

\begin{tabular}{|c|c|c|c|c|c|c|}
\hline \multicolumn{7}{|c|}{ By innovations in } \\
\hline Period & Rational $_{1}$ & Rational $_{2}$ & Irrational $_{1}$ & Irrational $_{2}$ & $\begin{array}{c}\text { Total Senti- } \\
\text { ments }\end{array}$ & Korea \\
\hline 1 & 4.0825 & 0.9269 & 0.0120 & 1.0277 & 5.0214 & 93.9509 \\
\hline
\end{tabular}




\begin{tabular}{lllllll}
\hline 2 & 4.0046 & 0.8984 & 0.7324 & 1.0486 & 5.6354 & 93.3160 \\
3 & 3.8057 & 3.9798 & 0.9001 & 2.6300 & 8.6855 & 88.6845 \\
4 & 3.7764 & 4.3255 & 0.9843 & 3.3019 & 9.0861 & 87.6119 \\
5 & 3.7690 & 4.4325 & 0.9838 & 3.3463 & 9.1853 & 87.4684 \\
6 & 3.7698 & 4.4903 & 0.9834 & 3.3466 & 9.2435 & 87.4099 \\
7 & 3.7687 & 4.5185 & 0.9835 & 3.3475 & 9.2707 & 87.3818 \\
8 & 3.7683 & 4.5267 & 0.9837 & 3.3483 & 9.2787 & 87.3731 \\
9 & 3.7683 & 4.5292 & 0.9837 & 3.3484 & 9.2812 & 87.3704 \\
10 & 3.7683 & 4.5302 & 0.9837 & 3.3483 & 9.2822 & 87.3694 \\
\hline
\end{tabular}

\subsection{Impulse response function}

Next, we analyze the impulse response functions to shed light on the significance and duration of the effect of shock in rational and irrational sentiments of individual investors to Pacific-Basin stock returns. It is well known theoretically that traditional orthogonalized forecast error variance decomposition results based on the widely used Choleski factorization of VAR innovations may be sensitive to variable ordering (Pesaran and Shin, 1996; Koop, Pesaran and Potter, 1996; Pesaran and Shin, 1998). To mitigate such potential problems of misspecifications, we employ the recently developed generalized impulses technique as described by Pesaran and Shin (1998) in which an orthogonal set of innovations which does not depend on the VAR ordering. The generalized impulse responses from an innovation to the $j^{\text {th }}$ variable are derived by applying a variable specific Cholesky factor computed with the $j^{\text {th }}$ variable at the top of the Cholesky ordering. These generalized impulses can capture the effect of unanticipated components and therefore can be regarded as an appropriate choice for this study.

Figures 1 a through $1 \mathrm{~d}$ plot the impulse responses of Hong Kong to rational and irrational sentiments of the U.S. individual and institutional investors. The response to rational sentiments for both individual and institutional are significant in the second month and becomes insignificant thereafter (figures 1 and 1c). However, the effect of the irrational component of sentiments is not significant in both the cases (figures $1 \mathrm{~b}$ and $1 \mathrm{~d}$ ). Figures $2 \mathrm{a}$ through $2 \mathrm{~d}$ plot the impulse responses of Malaysia to rational and irrational sentiments of the U.S. investors. Similar to the findings of Hong Kong, the responses to rational sentiments are significant in the second month and become insignificant thereafter (figures $2 \mathrm{a}$ and 2c). On the other hand the effect of irrational component of sentiments remains insignificant throughout (figures $2 b$ and $2 d$ ). Similarly in the case of Philippines, the responses of stock returns to the rational sentiments are significant 
(figures $3 \mathrm{a}$ and $3 \mathrm{c}$ ) while insignificant to the irrational components (figures $3 \mathrm{~b}$ and $3 \mathrm{c}$ ). The results of impulse responses of Singapore are somewhat similar in that rational (irrational) sentiments have significant (insignificant) influences on stock market returns (figures 4a through 4d). Positive significant effect of the shocks of rational sentiments in the case of Hong Kong, Malaysia, Philippines, and Singapore are consistent with earlier studies which find moderate linkages between these markets and the U.S. stock market movements.

Figure 1: Response of Hong Kong to the U.S. individual and institutional investor sentiments
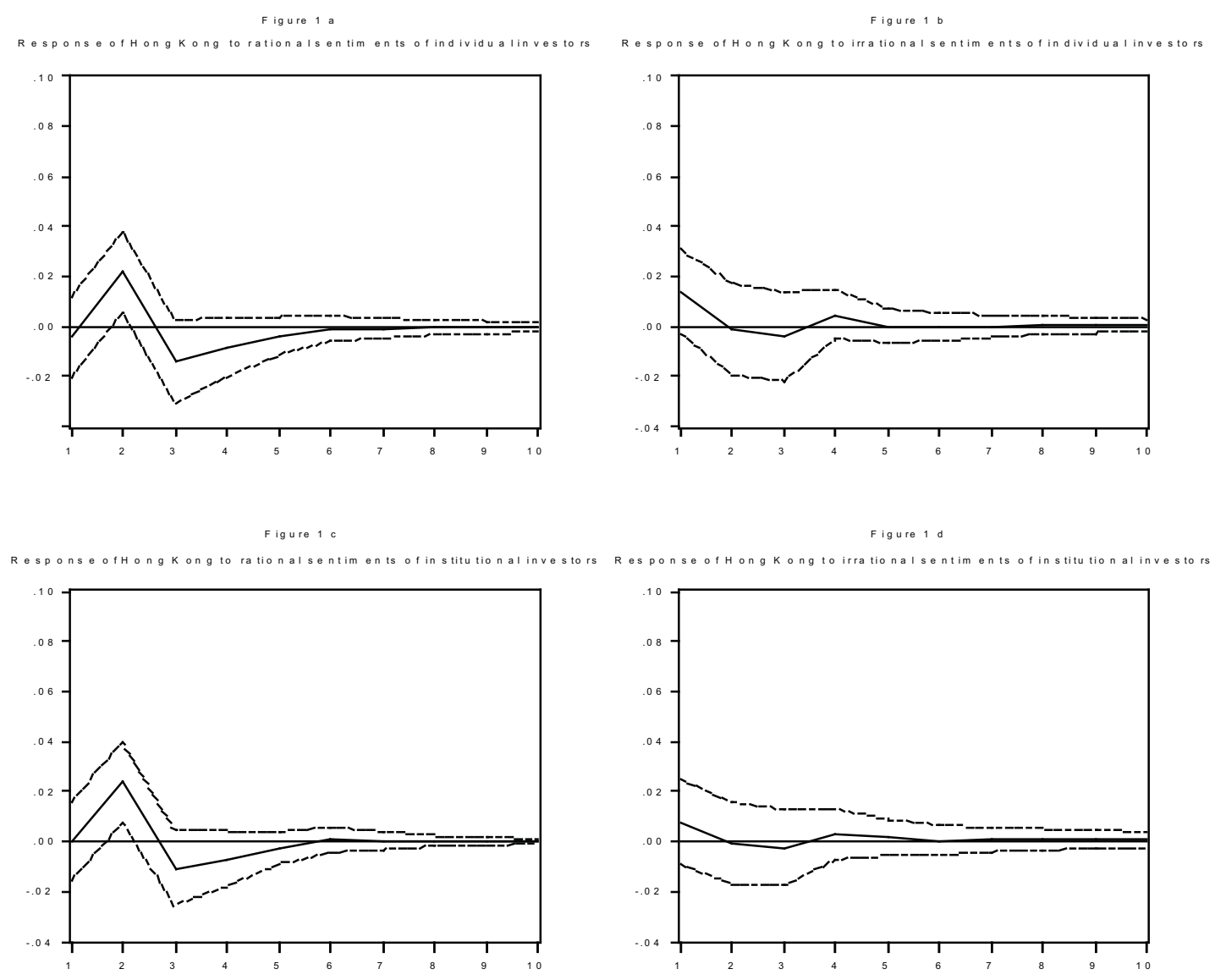

The dashed lines on each graph represent the upper and lower 95\% confidence bands. When the upper and lower bounds carry the same sign the response becomes statistically significant.

* On each graph, "percentage returns" are on the vertical and "horizon" is on the horizontal axis.

Figures 5a through $5 \mathrm{~d}$ plot the responses of Taiwan to the one unit shock in the rational and irrational sentiments of the U.S. individual and institutional investors. Unlike the results of Hong Kong, Malaysia, Philippines, and Singapore 
there are insignificant effects of rational components of both class of investors. Similarly, the irrational investor sentiments have insignificant effects on stock returns. We find similar results in the case of Thailand, where both the rational and irrational components of sentiments have insignificant effects (figure 6a through 6d). However, in the case of Korea there is significant effect of only rational sentiments of institutional investors (figure 7a). We find insignificant effect of rational sentiments of individual investors (figure 7c). Consistent with our earlier results there are insignificant effects of the irrational sentiments for both class of investors (figures $7 \mathrm{~b}$ and $7 \mathrm{~d}$ ). These insignificant results in the case of Taiwan, Thailand, and Korea are consistent with earlier studies such as Park and Fatemi (1993) which find little linkages of these markets with the U.S.

Figure 2: Response of Malaysia to the U.S. individual and institutional investor sentiments
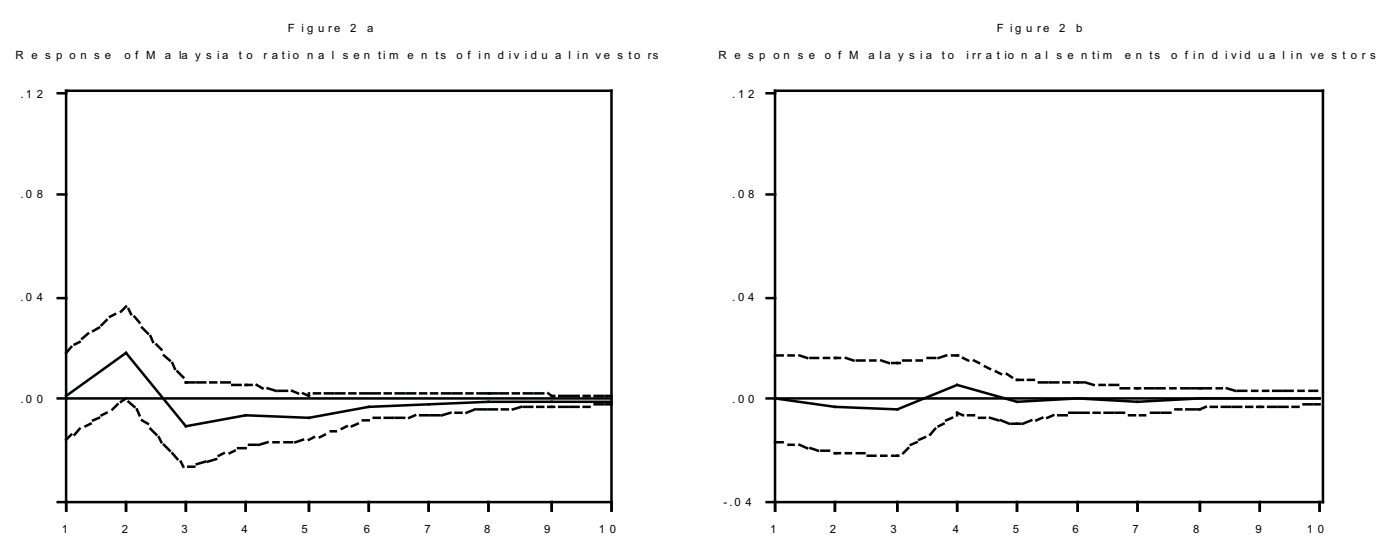

Figure 2 o

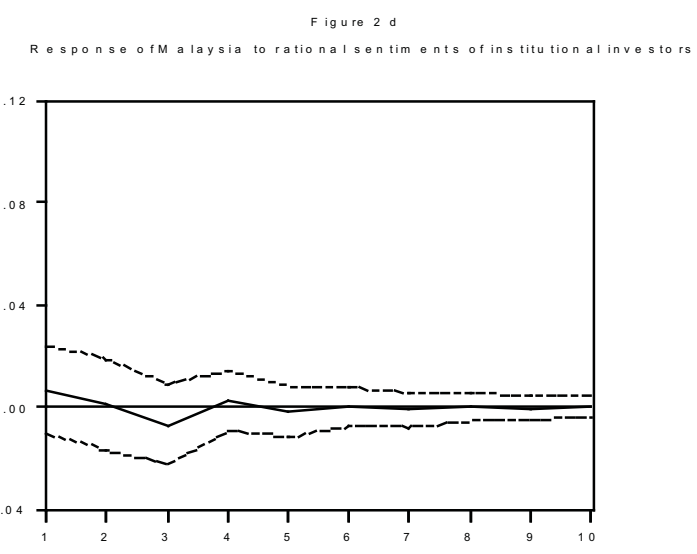

The dashed lines on each graph represent the upper and lower 95\% confidence bands. When the upper and lower bounds carry the same sign the response becomes statistically significant.

* On each graph, "percentage returns" are on the vertical and "horizon" is on the horizontal axis. 
Figure 3: Response of Philippines to the U.S. individual and institutional investor sentiments
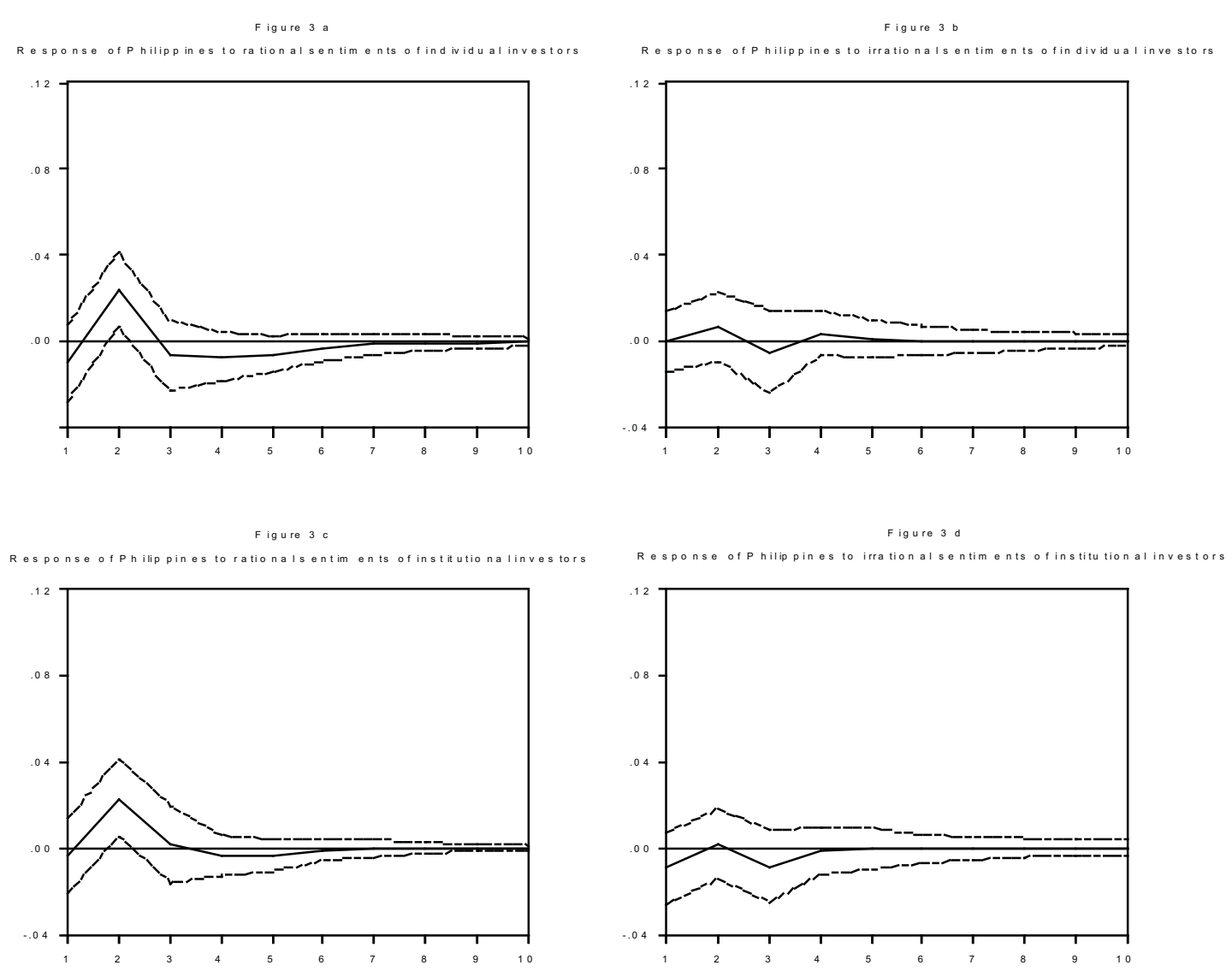

The dashed lines on each graph represent the upper and lower 95\% confidence bands. When the upper and lower bounds carry the same sign the response becomes statistically significant.

* On each graph, "percentage returns" are on the vertical and "horizon" is on the horizontal axis.

In all, the results of the variance decomposition and impulse responses strongly suggest that irrational exuberance of the U.S. investors, whether individual and institutional are not transmitted to the Pacific-Basin region. However, the rational both classes of investors are transmitted to Asian markets with varying degrees of intensity. Also, there are somewhat greater effects of the rational expectations of the U.S. institutional investors than those of the individual investors.

A significant development in emerging markets is that individual investors have increasingly delegated the management of their assets to professional fund managers (Griffith-Jones and Cailloux, 1998). Such institutionalization has increased the sensitivities of emerging markets to the behavior of international 
institutional investors. Moreover, it is much easier for domestic institutional investors engage in herding behavior compared to individual investors since similar information circulates among funds allowing them to follow more easily other institutions' decisions (Nofsinger and Sias, 1999). Also, due to the high transaction costs of investing in emerging markets, closed-end country funds have emerged as one of the most popular means of international investments by the U.S. individual investors. These factors may explain the greater responses of Pacific-Basin stock markets to the U.S. institutional investor sentiments as compared to the U.S. individual investor sentiments.

Figure 4: Response of Singapore to the U.S. individual and institutional investor sentiments
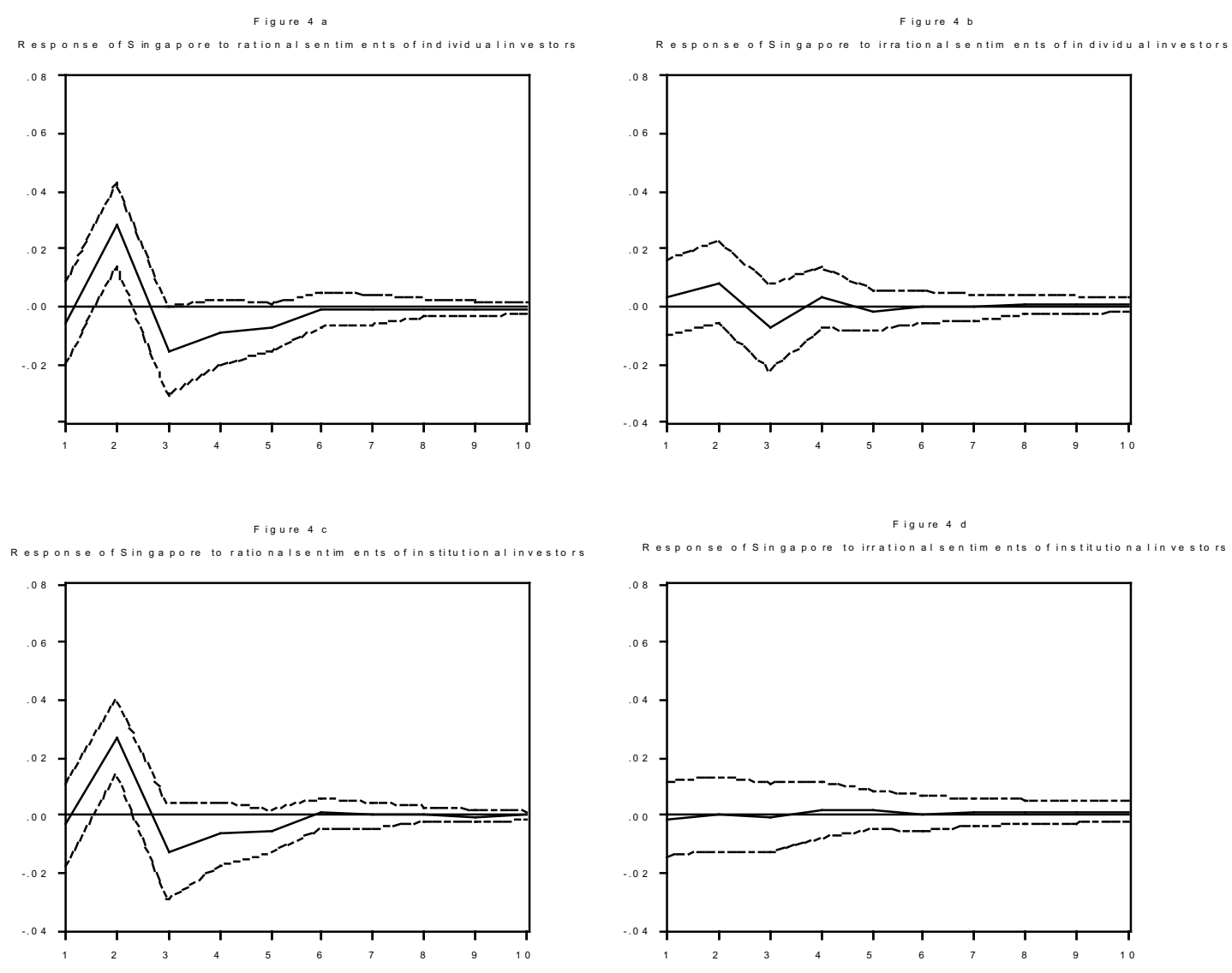

The dashed lines on each graph represent the upper and lower 95\% confidence bands. When the upper and lower bounds carry the same sign the response becomes statistically significant.

* On each graph, "percentage returns" are on the vertical and "horizon" is on the horizontal axis. 
Figure 5: Response of Taiwan to the U.S. individual and institutional investor sentiments
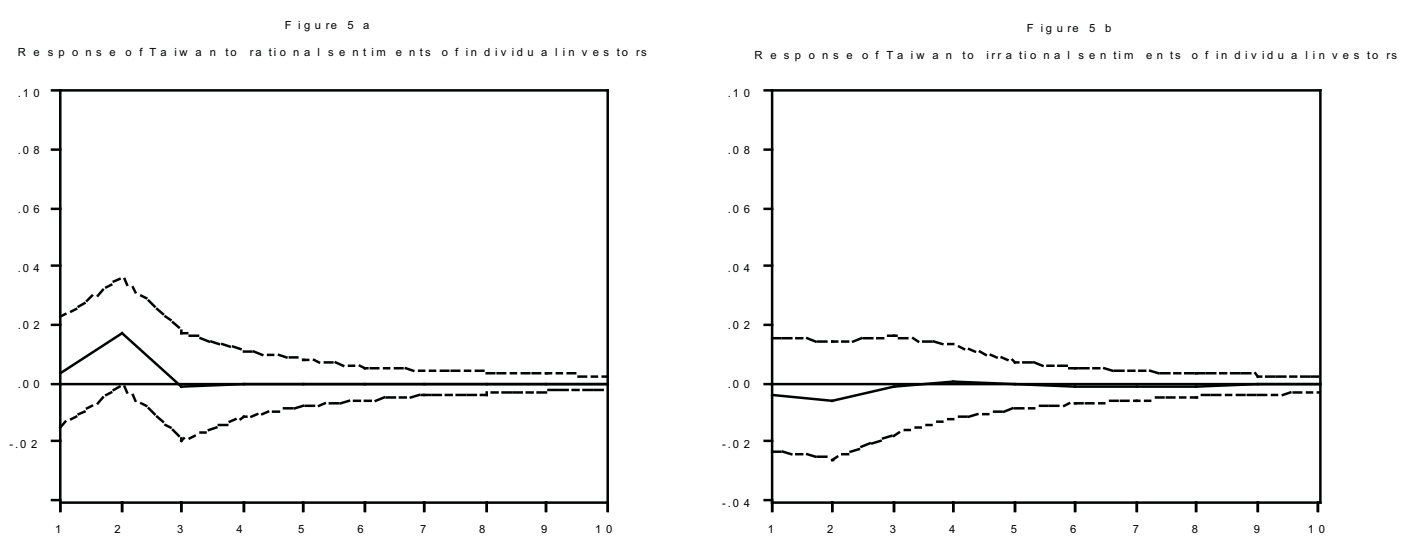

Figure 5 c
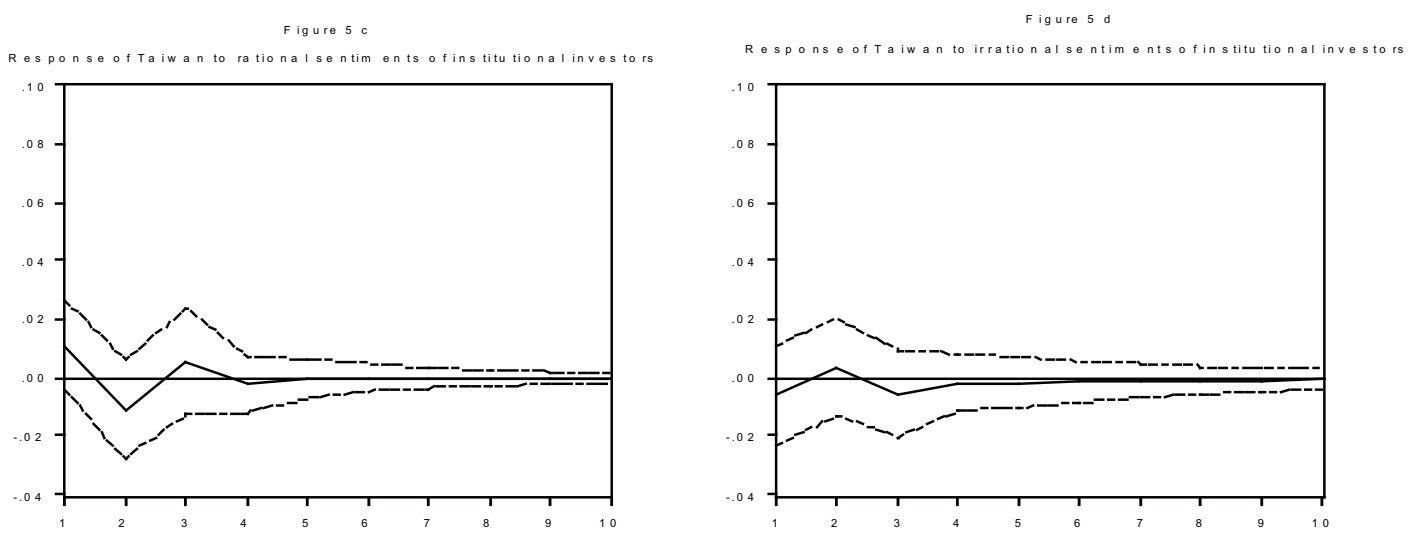

The dashed lines on each graph represent the upper and lower $95 \%$ confidence bands. When the upper and lower bounds carry the same sign the response becomes statistically significant.

* On each graph, "percentage returns" are on the vertical and "horizon" is on the horizontal axis. 
Figure 6: Response of Thailand to the U.S. individual and institutional investor sentiments
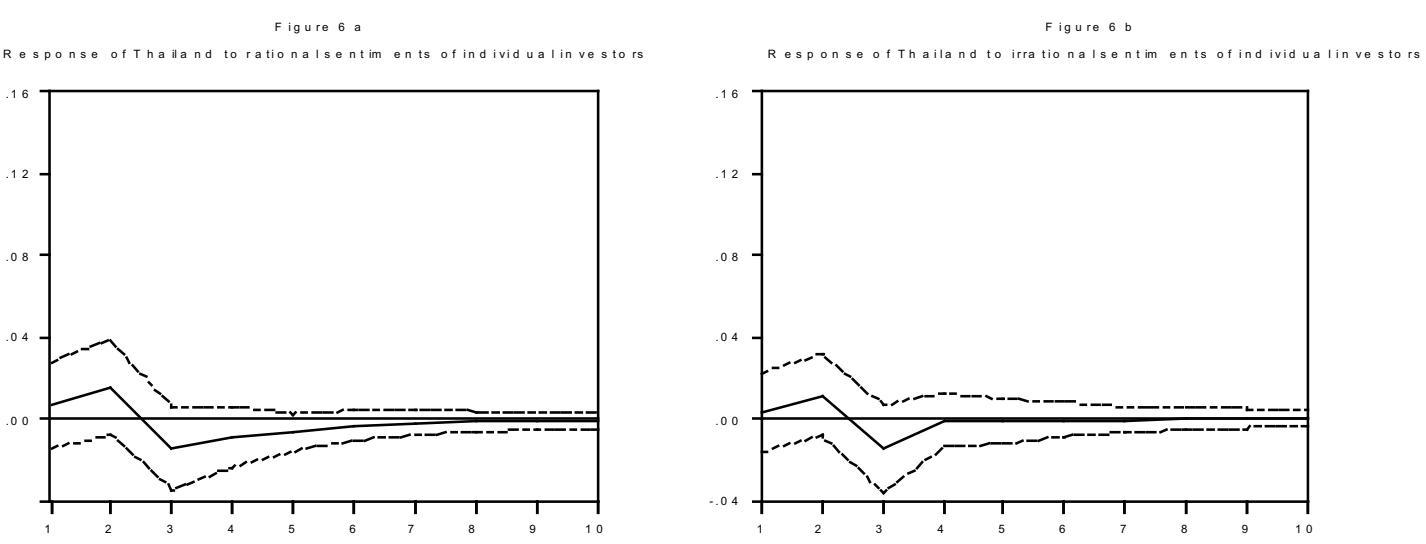

Figure 6 c
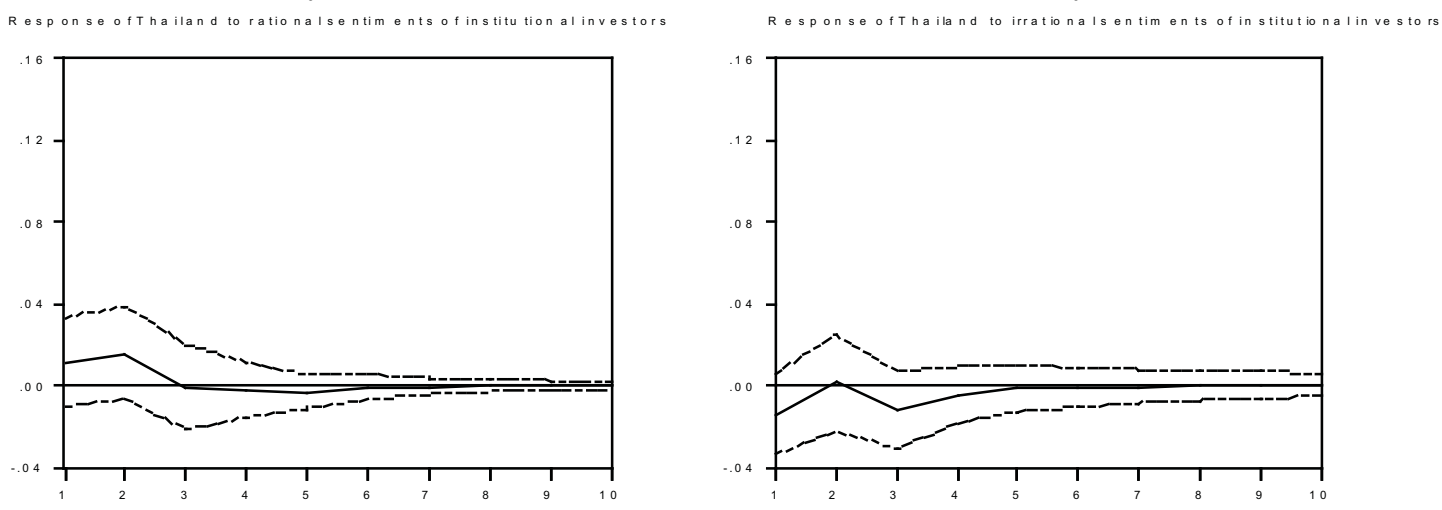

The dashed lines on each graph represent the upper and lower 95\% confidence bands. When the upper and lower bounds carry the same sign the response becomes statistically significant.

* On each graph, "percentage returns" are on the vertical and "horizon" is on the horizontal axis. 
Figure 7: Response of Korea to the U.S. individual and institutional investor sentiments
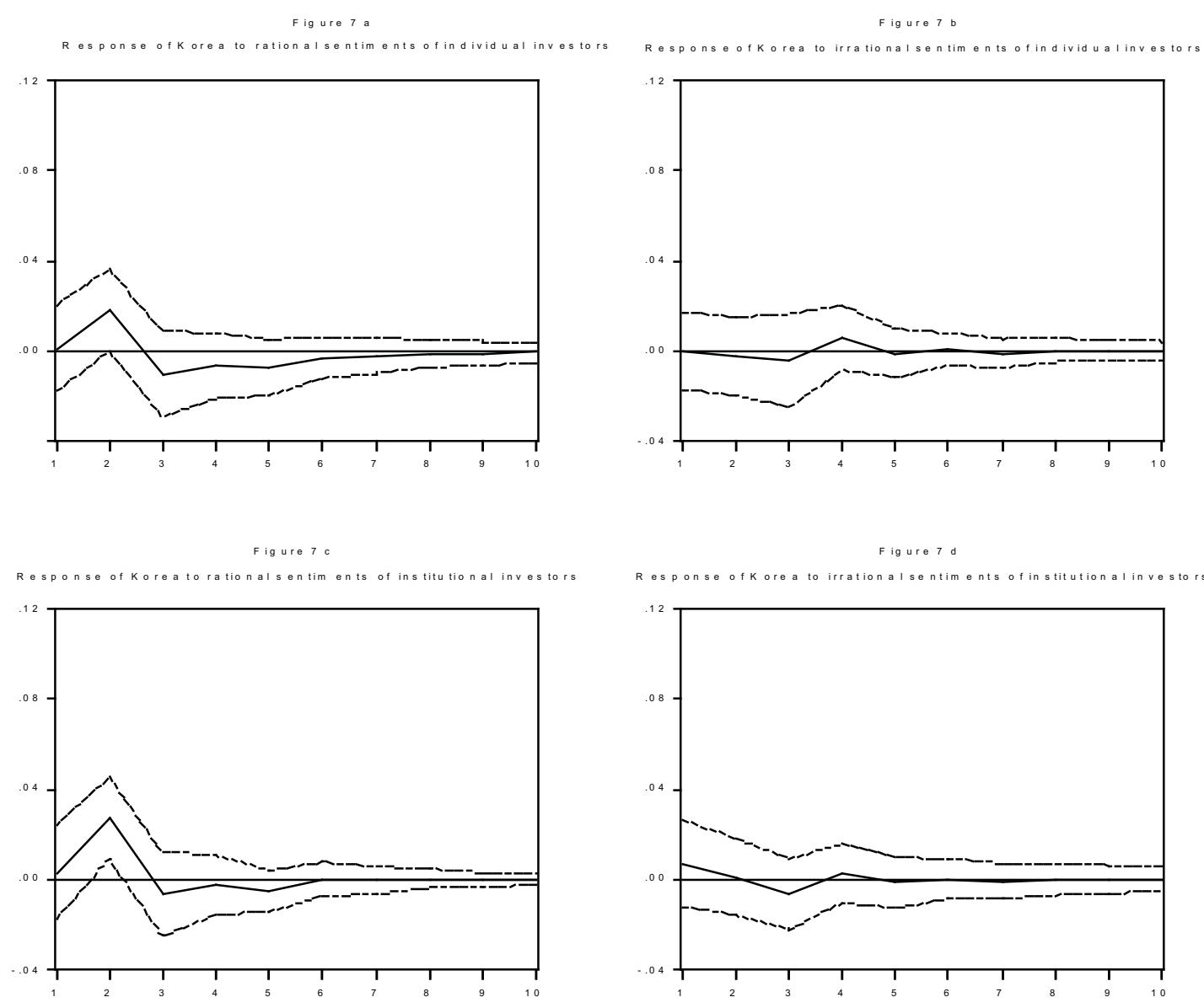

The dashed lines on each graph represent the upper and lower 95\% confidence bands. When the upper and lower bounds carry the same sign the response becomes statistically significant.

* On each graph, "percentage returns" are on the vertical and "horizon" is on the horizontal axis. expectations of

\section{Conclusion}

In this study, we investigate whether the rational expectations and irrational exuberance of the U.S. individual and institutional investors are propagated to Pacific-Basin stock markets, Hong Kong, Malaysia, Philippines, Singapore, Taiwan, Thailand, and Korea. We employ the investor sentiments data at the individual and institutional level, provided by American Association of Individual Investors and Investors Intelligence and the vector auto regression (VAR) models to investigate the postulated relationships. The results of variance decomposition and impulse response functions strongly suggest that there are distinct effects of the rational and irrational investor sentiments on these international stock market returns. 
We find strong evidence of insignificant effect of irrational exuberance of the U.S. investors on these set of Pacific-Basin stock market returns. However, the rational expectations of both the U.S. individual and institutional investors have significant effect on these Asian markets with varying degrees of intensity. We find greater effects in the case of Hong Kong, Malaysia, Philippines, and Singapore while a weak linkage with the stock returns of Taiwan, Thailand, and Korea. The overall evidence suggests that institutional investor sentiments are transmitted internationally from the U.S. stock market to a greater extent than the individual investor sentiments; and that the international effects of the U.S. stock market can be attributed to the sentiments induced by fundamental trading and not to noise trading. These results are consistent with the view that besides economic fundamentals, the international effects of the U.S. stock market can be attributed to rational investor sentiments. Therefore it is important for policymakers to consider such spillover effects in their international policy corporation and for investors in their portfolio allocation decisions involving stock markets movements.

Author statement: Rahul Verma, College of Business, University of HoustonDowntown. E-mail: vermar@uhd.edu. I like to record my thanks to the editors for receiving comments on the paper and making changes to the paper. The mistakes are my own responsibility.

\section{References}

Baker, M., and Wurgler, J. (2005). Investor sentiment and cross-section of stock returns. Journal of Finance, forthcoming.

Barberis, N., Shleifer, A., and Vishny, R. W., (1998). A model of investor sentiment. Journal of Financial Economics, 49: 307-343.

Black, F., (1986). Noise. The Journal of Finance, 41(3): 529-543.

Brown, G. W., and Cliff, M. T. (2004a). Investor sentiment and the near-term stock market. Journal of Empirical Finance 11(No. 1): 1-27.

Brown, G. W., \& Cliff, M. T., (2004b). Investor sentiment and asset Valuation. Journal of Business, (forthcoming).

Campbell, J. Y., (1987). Stock returns and the term structure. Journal of Financial Economics, 18: 373-399.

Campbell, J. Y. (1991). A variance decomposition for stock returns. Economic Journal, 101, 157-179.

Campbell, J. Y., (2000). Asset pricing at the millennium. Journal of Finance, 55 : $1515-1567$.

Campbell, J. Y., and Kyle, A. S., (1993). Smart money, noise trading, and stock price behavior. Review of Economic Studies, 60: 1-34.

Campbell, J. Y., and Shiller, R. J., (1988a). The dividend-price ratio and expectations of future dividends and discount factors. Review of Financial Studies, 1, 195-228. 
Campbell, J. Y., and Shiller, R. J., (1988b). Stock prices, earnings and expected dividends. Journal of Finance, 43: 661-676.

Chen, N., Kan, R., and Miller, M., (1993). Are the discounts on closed-end funds a sentiment index? Journal of Finance 48: 795-800.

Clarke, R. G., and Statman, M., (1998): Bullish or bearish? Financial Analysts Journal May/June, 63-72.

Cochrane, J. H. (2000). Asset Pricing. (Princeton University Press, Princeton, $\mathrm{NJ})$.

Daniel, K., Hirshleifer, D., and Subrahmanyam, A., (1998). Investor psychology and security market under- and overreactions. Journal of Finance 53: 1839-1886.

DeBondt, W., (1993). Betting on trends: Intuitive forecasts of financial risk and return. International Journal of Forecasting 9: 355-371.

DeLong, Shleifer, J., Summers, A., and Waldmann, R., (1990). Noise trader risk in financial markets. Journal of Political Economy, 98: 703-738.

DeLong, Shleifer, J., Summers, A., and Waldmann, R., (1991). The survival of noise traders in financial markets. Journal of Business, 64 (1): 1-19.

Dickey, D. A., and Fuller, W. A., (1979). Distribution of the estimators for autoregressive time series with a unit root. Journal of the American Statistical Association 74: 427-431.

Dickey, D. A., and Fuller, W. A., (1981). Likelihood ratio statistics for autoregressive time series with a unit root. Econometrica, 49: 10571072 .

Diebold, F. X., (2003). Elements of Forecasting. South Western College Publishing.

Doan, T., (1988). RATS User's Manual. Evanston, Illinois: VAR Econometrics.

Dolado, J. J., Jenkinson, T., and Sosvilla-Rivero, S., (1990). Cointegration and unit roots. Journal of Economic Surveys 4: 249-273.

Elton, E., J, Gruber, M., J, and Busse, J., A., (1998). Do investors care about sentiments? Journal of Business, 71: 477-500.

Elton, E. J., and Gruber, M. J. (1991). Modern Portfolio Theory and Investment Analysis. John Wiley and Sons, Inc., Fourth Edition.

Fama, E. F., (1965). The behavior of stock market prices. Journal of Business, 38 (No. 1): 34-105.

Fama, E. F., (1970). Efficient capital markets: A review of theory and empirical work.????????????

Fama, E. F. (1990). Term structure forecasts of interest rates, inflation, and real returns. Journal of Monetary Economics 25: 59-76.

Fama, E. F., and French, K. R. (1988). Dividend yields and expected stock returns. Journal of Financial Economics 22: 3-25.

Fama, E. F., and French, K. R. (1989). Business conditions and expected returns on stocks and bonds. Journal of Financial Economics, 25: 23-49.

Fama, E. F., and French, K. R., (1993). Common risk factors in the returns on stocks and bonds. Journal of Financial Economics 33: 3-56. 
Fama, E. F., and Schwert, G. W., (1977). Asset returns and inflation. Journal of Financial Economics, 5: 115-146.

Ferson, W. E., and Campbell, R. H., (1991). The variation in economic risk premiums. Journal of Political Economy 99: 385-415.

Fisher, K. L., and Statman, M., (2000). Investor sentiments and stock Returns. Financial Analysts Journal, March/April (16-23).

Friedman, M., (1953). Essays in positive economics. University of Chicago Press, Chicago.

Gemmill, G., and Thomas, C. D., (2002). Noise trading, costly arbitrage, and asset prices: evidence from closed-end funds. The Journal of Finance, 6 : (2571-2594).

Genberg, H., Salemi, M. K., and Swoboda, A. (1987). The relative importance of foreign and domestic disturbances for aggregate fluctuations in open economy: Switzerland. Journal of Monetary Economics 19: 45-67.

Gervais, S., and Odean, T. (2001). Learning to be overconfident. Review of Financial Studies 14: 1-28.

Hamilton, J. D., (1994). Time series analysis. Princeton University Press(Princeton, NJ).

Hirshleifer, D. (2001). Investor psychology and asset pricing. Journal of Finance, LVI(4): 1533-1597.

Hodrick, R., (1992). Dividend yields and expected stock returns: Alternative procedures for inference and measurement. Review of Financial Studies 5, 357-386.

Hong, H., Lim, T., and Stein, J. C., (2000). Bad news travels slowly: Size, analysts coverage and the profitability of momentum strategies. Journal of Finance, 55, 265-292.

Janakiramanan, S., and Lamba, A. S., (1998). An empirical examination of linkages between Pacific-Basin stock markets. Journal of International Financial Markets, Institutions and Money, 8, 155-173.

Jegadeesh, N., and Titman, S. (1993). Returns to buying winners and selling losers: Implications for stock market efficiency. Journal of Finance, 48, 65-91.

Kim, S.-J. (2003). The spillover effects of US and Japanese public information news in advanced Asia-Pacific stock markets. Pacific-Basin Finance Journal, 11, 611-630.

Koop, G., Pesaran, M. H., and Potter, S. M. (1996). Impulse response analysis in non linear multivariate models. Journal of Econometrics, 74, 119-147.

Kwiatkowski, D., Phillips, P. C. B., Schmidt, P., and Shin, Y. (1992). Testing the null hypothesis of stationarity against the alternative of a unit root: how sure are we that economic time series have unit root. Journal of Econometrics, 54, 169-178.

Keim, D. B., and Stambaugh, R. F. (1986). Predicting returns in the bond and stock markets. Journal of Financial Economics, 17, 357-390.

Lakonishok, J., Shleifer, A., and Vishny, R. W. (1991). Do Institutional investors destabilize stock prices? Evidence on herding and feedback Trading. Working Paper, NBER, 3846. 
Lee, C., Shleifer, A., and Thaler, R. (1991). Investor sentiment and the closedend fund puzzle. Journal of Finance, 46, 75-109.

Lee, W. Y., Jiang, C. X., and Indro, D. C., (2002). Stock market volatility, excess returns, and the role of investor sentiments. Journal of Banking \& Finance, 26, 2277-2299.

Lintner, J., (1965). Security prices, risk, and maximal gains from diversification. Journal of Finance.

Neal, R., and Wheatley, S., (1998). Do measures of investor sentiments predict stock returns? Journal of Financial and Quantitative Analysis, 34(523547).

Palomino, F. (1996). Noise trading in small Markets. Journal of Finance, 51(4), 1537-1550.

Park, J., and Fatemi, A. M., (1993). The linkages between the equity markets of Pacific-Basin countries and those of the U.S., U.K., and Japan: A vectorautoregression analysis. Global Finance Journal, 4(1): 49-64.

Pesaran, M. H., and Shin, Y., (1996). Cointegration and speed of convergence to equilibrium. Journal of Econometrics 71: 117-143.

Pesaran, M. H., and Shin, Y. (1998). Generalized impulse response analysis in linear multivariate models. Economics Letters 58: 17-29.

Ratanapakorn, O., and Sharma, S. C., (2002). Interrelationships among Regional Stock Indices. Review of Financial Economics, 11(91-108).

Schwert, G. W., (1990). Stock returns and real activity: A century of evidence. Journal of Finance, 45: 1237-1257.

Sharpe, S. A., (2002). Reexamining stock valuation and inflation: The implications of analysts' earnings forecasts. The Review of Economics and Statistics (forthcoming). ???

Sharpe, W. F. (1964)., Capital asset prices: A theory of market equilibrium under conditions of risk. Journal of Finance 425-442.

Shefrin, H., and Statman, M. (1994). Behavioral capital asset pricing theory. The Journal of Financial and Quantitative Analysis 29(3): 323-349.

Shleifer, A., and Summers, L. (1990). The noise trader approach to finance. Journal of Economic Perspectives, 4(2): 19-33.

Sias, R., W, Starks, L., T, \& Tinic, S., M., (2001). Is noise trader risk priced? The Journal of Financial Research, 24(3): 311-329.

Sims, C. (1980). Macroeconomic and reality. Econometrica, 48, 1-49.

Solt, M. E., and Statman, M., (1988). How useful is the sentiment Index? Financial Analysts Journal, September/October (45-55).

Soydemir, G. (2005). Differences in the price of risk and the resulting response to shocks: An analysis of Asian markets. Journal of International Financial Markets, Institutions and Money, 15: 285-313.

Swaminathan, B. (1996). Time-varying expected small firm returns and closedend fund discounts. Review of Financial Studies 9: 845-887.

Trueman, B. (1988). A theory of noise trading in securities markets. The Journal of Finance, 43(1): 83-95. 
94 The International Journal of Banking and Finance, 2008/09 Vol. 6. Number 1: 2008: 67-94

Wang, F. A.,(2001). Overconfidence, investor sentiment, and evolution. Journal of Financial Intermediation 10: 138-170.

West, K. (1988). Bubbles, fads and stock price volatility tests: A partial evaluation. The The Journal of Finance, 43(3): 639-565. 